\title{
Aged Lewis rats exposed to low and moderate doses of rotenone are a good model for studying the process of protein aggregation and its effects upon central nervous system cell physiology
}

Ratos Lewis idosos expostos a baixa e moderada doses de rotenona são um bom modelo para estudar o processo de agregação proteica e seus efeitos sobre a fisiologia celular do sistema nervoso central Michael F. Almeida', Carolliny M. Silvaํ, Aline M. D’Unhao ${ }^{1}$, Merari F. R. Ferrari ${ }^{1}$

\begin{abstract}
Cell physiology is impaired before protein aggregation and this may be more relevant than inclusions themselves for neurodegeneration. The present study aimed to characterize an animal model to enable the analysis of the cell biology before and after protein aggregation. Ten-month-old Lewis rats were exposed either to 1 or $2 \mathrm{mg} / \mathrm{kg} /$ day of rotenone, delivered subcutaneously through mini-pumps, for one month. Hyperphosphorylated TAU, alpha-synuclein, amyloid-beta peptide and protein carbonylation (indicative of oxidative stress) were evaluated in the hippocampus, substantia nigra and locus coeruleus through immunohistochemistry or western blot. It was found that $2 \mathrm{mg} / \mathrm{kg} /$ day rotenone increased amyloid-beta peptide, hyperphosphorylation of TAU and alpha-synuclein. Rotenone at $1 \mathrm{mg} / \mathrm{kg} / \mathrm{day}$ did not alter protein levels. Protein carbonylation remained unchanged. This study demonstrated that aged Lewis rats exposed to a low dose of rotenone is a useful model to study cellular processes before protein aggregation, while the higher dose makes a good model to study the effects of protein inclusions.
\end{abstract}

Keywords: protein aggregates; rats; neurodegeneration.

\section{RESUMO}

A fisiologia celular está prejudicada antes da agregação proteica podendo ser mais importante para a neurodegeneração do que as próprias inclusões. Assim, o objetivo deste estudo é caracterizar um modelo animal para analisar os mecanismos e efeitos da agregação proteica. Ratos Lewis com 10 meses de idade foram expostos a rotenona (1 ou $2 \mathrm{mg} / \mathrm{kg} / \mathrm{dia}$ ), administrada subcutaneamente, utilizando minibombas osmóticas. Os níveis de peptídeo beta-amiloide, TAU hiperfosforilada, alfa-sinucleína e proteínas carboniladas (indicativo de estresse oxidativo) foram avaliados por imunohistoquímica e western blot no hipocampo, substância negra e locus coeruleus. Foi demonstrado que $2 \mathrm{mg} / \mathrm{kg} /$ dia de rotenona promoveu aumento do peptídeo beta-amiloide, hiperfosforilação da TAU e alfa-sinucleína. Já $1 \mathrm{mg} / \mathrm{kg} / \mathrm{dia}$ de rotenona não alterou os níveis dessas proteína nessas regiões. As proteínas carboniladas não se alteraram. Foi demonstrado que ratos Lewis idosos expostos a baixas doses de rotenona são modelo de estudo dos processos celulares antes da agregação proteica, enquanto $2 \mathrm{mg} / \mathrm{kg} /$ dia de rotenona permite estudos sobre os efeitos da agregação proteica.

Palavras-chave: agregados proteicos; ratos; neurodegeneração.

Increase in lifespan is the reality for a number of countries around the world and is frequently associated with a rise in chronic diseases such as hypertension, diabetes, cancer, chronic obstructive pulmonary disease, visual impairment and neurodegeneration ${ }^{1}$, such as Alzheimer's and Parkinson's diseases.
Amyloid-beta $(A \beta)$ peptides and hyperphosphorylated TAU proteins are always present in the hippocampus of Alzheimer's patients ${ }^{2,3}$. Lewy bodies, mainly constituted of alpha-synuclein, are distributed in the substantia nigra and locus coeruleus and are related to Parkinson's disease ${ }^{4}$.

'Universidade de São Paulo, Instituto de Biociências, Departamento de Genética e Biologia Evolutiva, São Paulo SP, Brasil.

Correspondence: Merari F. R. Ferrari; Instituto de Biociências, Departamento de Genética e Biologia Evolutiva, USP; Rua Matao, 277; 05508-090 São Paulo SP, Brasil; E-mail: merari@usp.br

Conflict of interest: There is no conflict of interest to declare.

Support: This study was supported by research grants from Fundacao de Amparo a Pesquisa do Estado de Sao Paulo (FAPESP) (2013/08028-1; 2015/18961-2) and Conselho Nacional de desenvolvimento Cientifico e Tecnologico (CNPq) (471999/2013-0; 401670/2013-9). M.F.A and C.M.S. received fellowships from FAPESP; A.M.D. received fellowship from CNPq.

Received 04 January 2016; Received in final form 03 June 2016; Accepted 08 June 2016. 
Although protein aggregates are often present during the course of neurodegeneration, it is well accepted that early stages of aggregation are more important than protein inclusions themselves for cell death ${ }^{5,6,7}$.

There is strong evidence that cell physiology is impaired before protein aggregation, for instance, changes in intracellular trafficking ${ }^{8,9}$, alteration in shape, function and localization of mitochondria, synaptic deficiency ${ }^{10,11}$, oxidative stress ${ }^{12}$, endoplasmic reticulum stress and lysosome dysfunction ${ }^{13}$ are some of the cell alterations that appear in early neurodegeneration and may play an important role during neuron loss.

Reactive oxygen/nitrogen species can interact with proteins, nucleic acids, lipids and other cellular molecules. Oxidative stress damage can specifically be evaluated by protein carbonylation, which is a widespread and irreversible oxidative modification in protein structure where no repair system has been described to date ${ }^{14}$.

Rotenone is a natural pesticide, an inhibitor of mitochondrial complex I, which currently is being employed to model neurodegenerative diseases, since exposure to it triggers cellular and molecular alterations common to a variety of neurodegenerative diseases ${ }^{15,16}$. Nevertheless, rotenone is useful in understanding neurodegeneration associated with protein aggregation and for testing neuroprotective strategies ${ }^{17}$.

In view of this, this study aimed to examine the effects of low and moderate doses of rotenone on TAU hyperphosphorylation, $A \beta$ formation, alpha-synuclein expression and oxidative stress in the brain of aged rats.

The intent of the present study is contribute to translational science regarding the understanding of the cellular cause and effects of protein inclusions during neurodegeneration, since the protocol described here is a valuable tool for studying the process of protein aggregation.

\section{METHODS}

All procedures were performed in accordance with the International Guideline for Animal Experimentation care and use, as well as respecting the Brazilian federal law 11794/08 for animal welfare and approved by the institutional ethics committee (CEUA 451/11) of the Department of Genetics and Evolutionary Biology, Institute for Biosciences, University of Sao Paulo.

\section{Animals and exposure to rotenone}

Twenty-two aged male Lewis rats (10 months old), supplied by the central animal facility of the Institute of Biosciences of the University of Sao Paulo were used in this study. The animals were housed in groups of three to four animals per conventional cage, maintained at $23^{\circ} \mathrm{C} \pm 2$, in 12 - $\mathrm{h}$ light/12-h dark cycle (lights on at $7 \mathrm{am}$ ), with free access to food and water.
Aged male Lewis rats were anesthetized with ketamine $(1.25 \mathrm{ml} / \mathrm{kg})$ and xylazine $(0.5 \mathrm{ml} / \mathrm{kg})$, and had osmotic minipumps (4ML2, Alzet, USA) implanted subcutaneously on their back. The minipumps were filled either with rotenone (Sigma, USA) dissolved in equal volumes of dimethyl sulfoxide (DMSO, Sigma, USA) and polyethylene glycol (PEG, Sigma, USA), which was delivered at the rate of either $1 \mathrm{mg} / \mathrm{kg} /$ day or $2 \mathrm{mg} / \mathrm{kg} /$ day for four weeks, or only DMSO:PEG (1:1) as the control.

After treatment, seven aged rats (three for DMSO group; two for ROT $1 \mathrm{mg} / \mathrm{kg} /$ day and two for ROT $2 \mathrm{mg} / \mathrm{kg} /$ day), were deeply anaesthetized (according to the method already described for implantation of minipumps) and perfused with saline (0.9\%) followed by a fixative solution consisting of $4 \%$ paraformaldehyde $(\mathrm{w} / \mathrm{v})$ and $0.2 \%$ picric acid (v/v) in $0.1 \mathrm{M}$ PBS, $\mathrm{pH} 6.9$, at $4^{\circ} \mathrm{C}$. Brain tissues containing the substantia nigra, hippocampus and locus coeruleus were removed and fixed for an additional 90 minutes in the fixative solution described above, followed by incubation in sucrose diluted in PBS for 48 hours (the sucrose was changed every 24 hours). Brain sections $(14 \mu \mathrm{m})$ were obtained in a cryostat (Leica, CM3050, Germany), at $-25^{\circ} \mathrm{C}$.

The other 15 aged rats ( five for each group: DMSO, ROT1 and ROT2) were anesthetized (as detailed for implantation of minipumps) and decapitated to have their substantia nigra, hippocampus and locus coeruleus removed, rapidly collected and stored at $-80^{\circ} \mathrm{C}$ in extraction buffer $(400 \mu \mathrm{l}$ of PBS, pH 7.4, containing $1 \%$ NP40, $0.5 \%$ sodium deoxycholate, $1 \%$ SDS, 1mM EDTA, 1mM EGTA and $1 \%$ protease inhibitor cocktail (Sigma) to be evaluated by western blot.

\section{Identification of protein aggregates through immunohistochemistry}

Imunohistochemical analysis of protein aggregation was evaluated in three slices/region/animal, with a total of 15 slices/region/animal taken, between Bregma levels from $-3.6 \mathrm{~mm}$ to $-4.1 \mathrm{~mm}$ for the hippocampus, $-5.5 \mathrm{~mm}$ to $-5.8 \mathrm{~mm}$ for the substantia nigra and -9.6 to -10.0 for the locus coeruleus. The whole hippocampus, substantia nigra and locus coeruleus were analyzed, without any distinction of the subarea (hippocampus: $\mathrm{CA}$ /dentate gyrus; substantia nigra: pars compacta/pars reticulata)

Sections were incubated for 24 hours at $4^{\circ} \mathrm{C}$ with antibodies against either hyperphosphorylated TAU 1/200 (Santa Cruz Biotechnology, sc-101813), alpha-synuclein 1/200 (Abcam, ab1903) or amyloid-beta peptide 1/200 (Abcam, ab14220), followed by incubation with biotinylated secondary goat anti-rabbit immunoglobulin antibodies $(1 / 230$, Vector, USA) for $90 \mathrm{~min}$. Sections were then incubated with avidin-biotin peroxidase complex (1:120, Vectastain, Vector, USA) for 45 minutes and immunoreactivity was visualized using 3-3'-diaminobenzidine tetrahydrochloride (DAB, Sigma) as chromogen and $\mathrm{H}_{2} \mathrm{O}_{2}(0.05 \%)$ 
for six minutes of reaction. Cells were counterstained with hematoxylin, which is a valuable tool to stain nuclei. The use of hematoxylin facilitates intracellular localization of protein aggregates.

\section{Western blot analysis of protein aggregation}

Brain tissue containing the substantia nigra, hippocampus and locus coeruleus were homogenized, separately, in $400 \mu \mathrm{l}$ of PBS, pH 7.4, containing 1\% NP40, 0.5\% sodium deoxycholate, $1 \%$ SDS, $1 \mathrm{mM}$ EDTA, $1 \mathrm{mM}$ EGTA and 1\% protease inhibitor cocktail (Sigma). After centrifugation at 14,000 rpm for 20 minutes, the protein concentration was accessed using the Bradford method. Total protein was fractionated by SDS-PAGE (15 $\mu$ g of protein/lane) using a $12 \%$ tris- $\mathrm{HCl}$ gel at $100 \mathrm{~V}$ for one hour. Proteins were transferred to nitrocellulose membrane in transfer buffer $(25 \mathrm{mM}$ Tris, $190 \mathrm{mM}$ glycine, $10 \%$ methanol) for one hour at 100 $\mathrm{V}$ at $4^{\circ} \mathrm{C}$. Membranes were blocked for one hour at room temperature in Tris-buffered saline containing Tween 20 (TBS-T; 50 mM Tris, pH 8.0, 133 mM NaCl, 0,2\% Tween 20) with $5 \%$ non-fat dry milk.

Blots were incubated with primary antibodies against alpha-synuclein (Abcam ab1903) diluted 1/500 or hyperphosphorylated TAU (Sigma-Aldrich, T6819) 1/1000 in $3 \%$ milk/TBS-T, overnight at $4^{\circ} \mathrm{C}$, followed by horseradish peroxidase-conjugated anti-mouse 1/6000 (Amersham) or antirabbit 1/10000 (Amersham). Secondary antibody incubations were performed at room temperature for one hour.

Development was done after a five-minute incubation with an enhanced chemiluminescence reagent (Millipore) and exposure to chemiluminescent-sensitive films (Hyperfilm ECL, Amersham). After development, blots were incubated with anti-beta-actin antibody 1/1000 (Santa Cruz Biotechnology, sc47778) for one hour at room temperature, followed by horseradish peroxidase conjugated anti-mouse (Amersham) diluted $1 / 6000$, incubated for one hour also at room temperature and were developed as previously described.

Films were quantified using Image J software (NIH). Normalization was done by dividing the values corresponding to the bands relative to proteins of interest by beta-actin values. Experiments were performed in triplicate and repeated twice.

\section{Protein carbonyls assay}

Protein carbonylation levels in soluble proteins were measured with Oxiselect Protein Carbonyl Immunoblot Kit (Cell Biolabs, Inc., San Diego, CA, USA). Protein carbonyls were derivatized with 2,4-dinitrophenylhydrazine (DNPH) and detected by western blot method.

Briefly, $70 \mu \mathrm{g}$ of proteins homogenates were fractionated in an SDS-polyacrylamide gel and transferred to nitrocellulose membranes as previously described. Membranes were then equilibrated in TBS containing $20 \%$ methanol for five minutes, washed in $2 \mathrm{~N} \mathrm{HCl}$ for five minutes and incubated with DNPH solution for five minutes for derivatization. This was followed by three washes in $2 \mathrm{~N} \mathrm{HCl}$ and five washes with $50 \%$ methanol, for five minutes each. Finally, membranes were blocked for one hour at room temperature in TBS-T with 5\% non-fat dry milk.

Blots were incubated with anti-beta-actin antibody 1/1000 (Santa Cruz, sc-47778) for one hour at room temperature, followed by horseradish peroxidase conjugated secondary antibody anti-mouse (Amersham) diluted 1/6000 for one hour also at room temperature and developed as previously described for normalization.

Protein carbonylation was evaluated by incubating the DNPH-treated membranes with primary rabbit antibody against DNP (part. no. 230801), diluted 1/1000 in $5 \%$ milk/PBS (9.1 mM Na $\mathrm{HPO}_{4}, 1.7 \mathrm{mM} \mathrm{NaH} \mathrm{PO}_{4}, 150 \mathrm{mM}$ $\mathrm{NaCl}, \mathrm{pH} 7.4$ ), overnight at $4^{\circ} \mathrm{C}$. After incubation, membranes were washed in TBS-T and incubated in an antirabbit phosphatase-conjugated antibody (Kirkegaard and Perry Laboratories, KPL) diluted 1/10000 in 3\% milk/PBS for one hour at room temperature.

Labeling was developed after washing membranes in TBS-T and TBS and incubating for 15 minutes with BCIP/NBT phosphatase substrate (KPL, USA).

Normalization and DNP stain quantification were done as previously described. The experiments were performed in triplicate and repeated three times.

\section{Statistical analysis}

Results were analyzed by one-way ANOVA followed by the Bonferroni post-hoc test or unpaired Student's T test, both accessed through GraphPad Prism (GraphPad Software Inc., version 5.00, CA). Data are expressed as mean \pm standard deviation (SD). A p-value $\leq 0.05$ was considered statistically significant.

\section{RESULTS}

\section{Hippocampus}

The presence of protein aggregates in the hippocampus is a hallmark of several neurodegenerative diseases such as Alzheimer's disease and frontotemporal dementia, as these protein aggregates are mainly composed of TAU and $A \beta$. To evaluate whether rotenone exposure could induce the formation of these aggregates, we performed immunohistochemical assays targeting $A \beta$ and TAU. Immunohistochemical labeling demonstrated that aged Lewis rats exposed to $2 \mathrm{mg} / \mathrm{kg} /$ day of rotenone showed positive immunorreactivity for $A \beta$ and hyperphosphorylated TAU compared to DMSO-exposed rats (Figure 1A-D).

To further describe rotenone's ability to trigger protein aggregation, we measured hyperphosphorylated TAU levels, since TAU hyperphosphorylation is one of the key process that precede TAU aggregation. Hyperphosphorylated 
TAU levels significantly increased $(84 \%, \mathrm{p}=0.03)$ following exposure to $2 \mathrm{mg} / \mathrm{kg} /$ day of rotenone compared to DMSOexposed rats (Figure 1E) supporting the detection of TAU aggregates after exposure to rotenone.

Interestingly, exposure to $1 \mathrm{mg} / \mathrm{kg} /$ day of rotenone neither induced $\mathrm{A} \beta$ and TAU aggregation (data not shown) nor modulated hyperphosphorylated TAU levels (Figure 1E, p = 0.42), suggesting that rotenone effects are dose-dependent.

Rotenone is widely employed to mimic Parkinson's disease pathology through its ability to disrupt alphasynuclein levels and induce oxidative stress in the substantia nigra. Therefore, we evaluated whether TAU and A $\beta$ aggregation observed in the hippocampus were associated with dysfunctions in alpha-synuclein and/or protein carbonylation levels. We did not observed significant alteration in alpha-synuclein (Figure 1F, p = 0.48) or protein carbonylation levels compared to DMSO (Figure $1 \mathrm{G}$ and $1 \mathrm{H}, \mathrm{p}=0.56$ ), according to one-way ANOVA followed by the Bonferroni post-hoc test, following exposure to 1 or $2 \mathrm{mg} / \mathrm{kg} /$ day of rotenone.

\section{Substantia nigra}

Substantia nigra degeneration is a distinguishing hallmark of Parkinson's disease with the formation of alpha-synuclein aggregates being reported as the major neurodegenerative insult triggering this process. Thus, we evaluated rotenone's ability to induce alphasynuclein aggregation. Immunohistochemical analysis of alpha-synuclein demonstrated that aged Lewis rats exposed to $2 \mathrm{mg} / \mathrm{kg} /$ day of rotenone presented alpha-synuclein dense labeling, however the exposure to $1 \mathrm{mg} / \mathrm{kg} /$ day was not sufficient to stimulate protein aggregation in the substantia nigra (Figure 2A-C).

We hypothesized that the rotenone ability to trigger alpha-synuclein aggregation could be related with TAU dysfunction, and our analysis demonstrated a massive increase $(300 \%, p=0.01)$ in hyperphosphorylated TAU levels after exposure to the highest dose of rotenone, compared to DMSO (Figure 2D), thus supporting our hypothesis.

To evaluate whether alpha-synuclein aggregation was triggered by up-regulation in alpha-synuclein and/or protein carbonylation levels, we performed western blot analyses. Changes were not observed in alpha-synuclein or protein carbonylation levels in aged Lewis rats exposed to rotenone compared to DMSO (Figure 2E, $2 \mathrm{~F}$ and $2 \mathrm{G} ; \mathrm{p}=0.35$ and $\mathrm{p}=0.61$, respectively), according to oneway ANOVA followed by the Bonferroni post-hoc test,
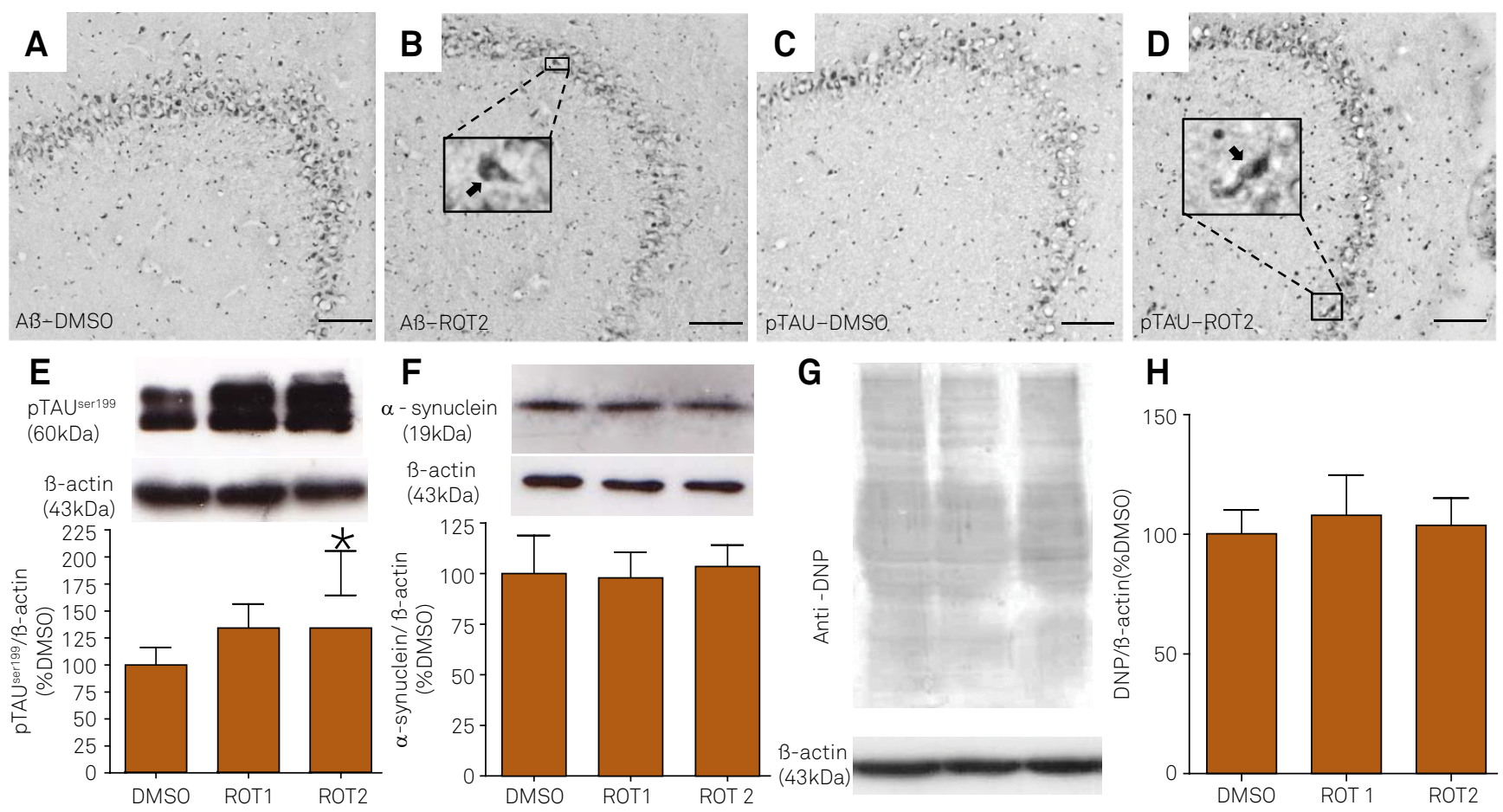

Figure 1. Illustrative digital images showing the pattern of amyloid-beta peptide (A $\beta, A$ and B) and hyperphosphorylated TAU (p-TAU, $C$ and D) immunoreactivities in the hippocampus (CA3 region) of 10-month-old rats exposed to DMSO or rotenone $(2 \mathrm{mg} / \mathrm{kg} / \mathrm{day}$, ROT2). Arrows indicate cells with dense cytoplasm labelling suggestive of aggregates containing $A \beta$ and $p$-TAU (details in B and D). Scale bar $=50 \mu \mathrm{m}$. Representative images of immunoblot bands corresponding to p-TAU, alpha-synuclein and beta-actin and quantification of their expression (E and F, respectively) in the hippocampus of aged rats exposed either to DMSO or rotenone (1 or $2 \mathrm{mg} / \mathrm{kg} /$ day, ROT1 or ROT2). Protein carbonyls were evaluated using antibody against DNP (dinitrophenol) ( $\mathrm{G}$ and $\mathrm{H}$ ). Normalizations were performed by beta-actin signal. Values are shown as a percentage of the control (DMSO) $\pm S D$. ${ }^{*} p<0.05$ as compared to DMSO. Experiments were repeated twice, each was run in technical triplicate. 
suggesting the existence of an alternative pathway triggering alpha-synuclein aggregation.

\section{Locus coeruleus}

Locus coeruleus degeneration is reported in Parkinson's and Alzheimer's diseases and evidence suggests that alterations in this brain region could even precede the impairment of brain regions classically associated with these diseases.

Besides the hippocampus and substantia nigra, the exposure to $2 \mathrm{mg} / \mathrm{kg} /$ day of rotenone triggered alpha-synuclein dense labeling in the locus coeruleus of aged Lewis rats (Figure 3A, 3B and 3C). Exposure to $1 \mathrm{mg} / \mathrm{kg} /$ day of rotenone did not change alpha-synuclein or hyperphosphorylated TAU expression levels (Figure 3D-F, $\mathrm{p}=0.37$ and $\mathrm{p}=0.44$, respectively) or protein carbonyls levels (Figure $3 \mathrm{G}$ and $3 \mathrm{H}, \mathrm{p}=0.21$ and $\mathrm{p}=0.58$, respectively), according to the unpaired Student's T test.

\section{DISCUSSION}

The results presented herein showed that $1 \mathrm{mg} / \mathrm{kg} /$ day of rotenone delivered subcutaneously to 10-month-old Lewis rats did not alter $A \beta$ peptide and hyperphosphorylated TAU levels in brain regions. Exposure to $2 \mathrm{mg} / \mathrm{kg} /$ day triggered aggregation of the $\mathrm{A} \beta$ peptide and hyperphosphorylated TAU in the hippocampus, and alpha-synuclein in the substantia nigra and locus coeruleus as visualized by immunohistochemistry. Western blot results showed increased hyperphosphorylated TAU levels in the hippocampus and substantia nigra after exposure to $2 \mathrm{mg} / \mathrm{kg} /$ day of rotenone.

Although rotenone was originally associated with Parkinson's disease models it is now well accepted as a model for studying neurodegenerative diseases, especially considering the process of protein aggregation ${ }^{8,16}$. Moreover, in vitro models of neurodegeneration, using either primary cell cultures or cell lineages, corroborate the ability of rotenone to promote protein aggregation depending on the pesticide concentration $^{18,19}$. The present study also observed $A \beta$ peptide in the hippocampus of aged Lewis rats after exposure to $2 \mathrm{mg} / \mathrm{kg} /$ day of rotenone.

The immunohistochemistry assays were done aiming to qualitatively access the existence of protein aggregation. The number of animals used for immunohistochemistry was two or three for each experimental condition, and
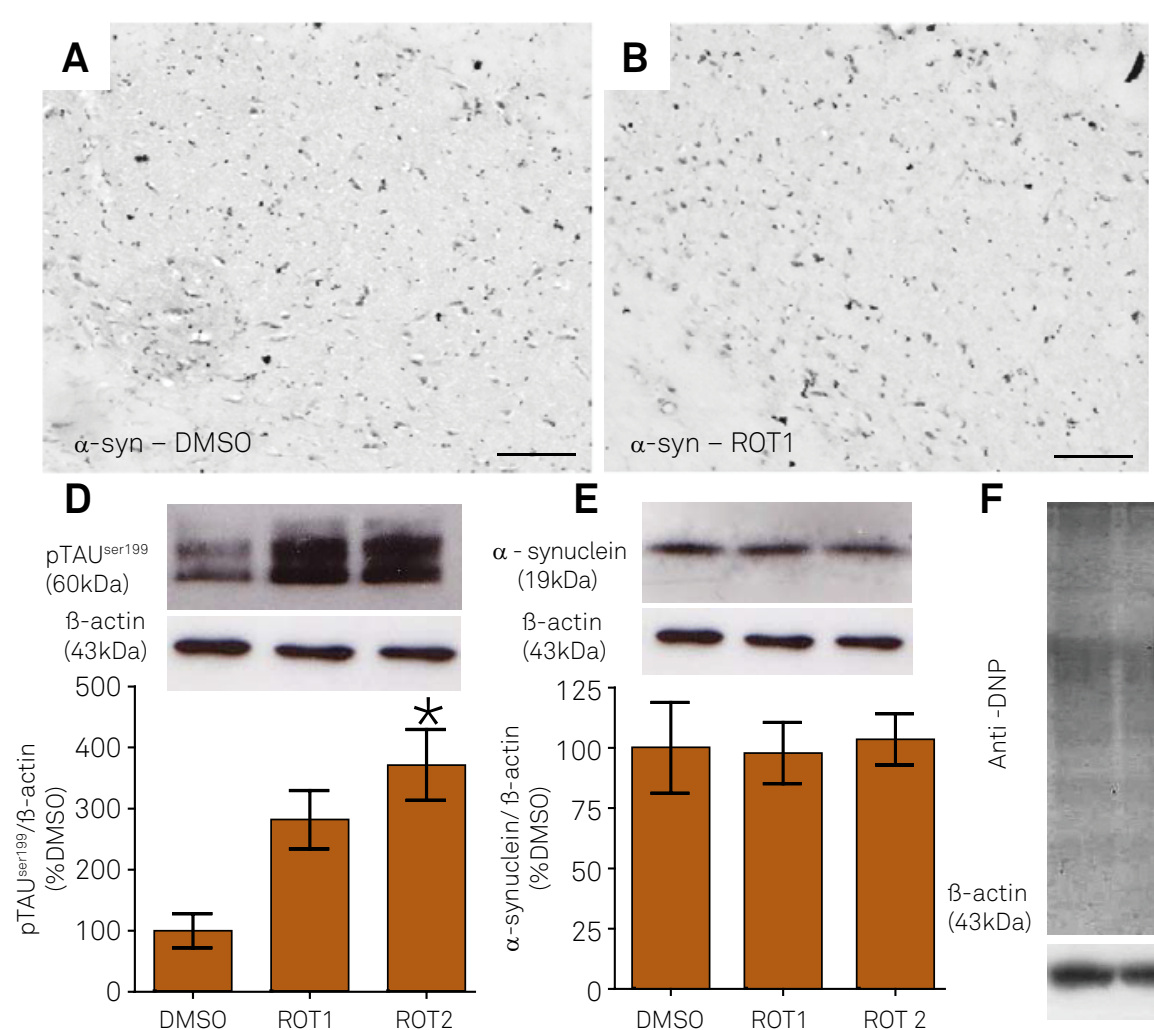

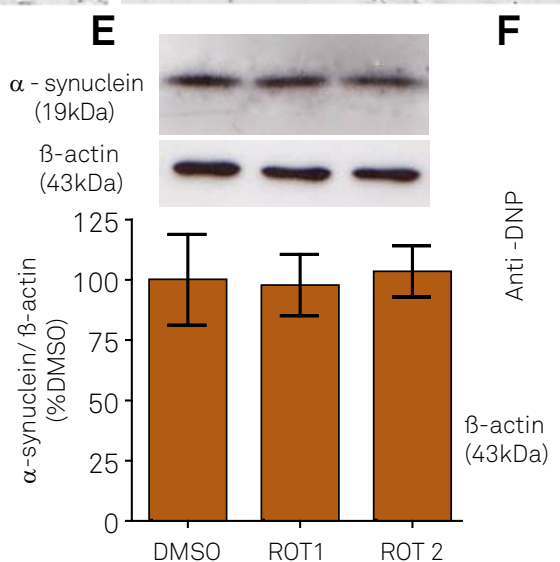

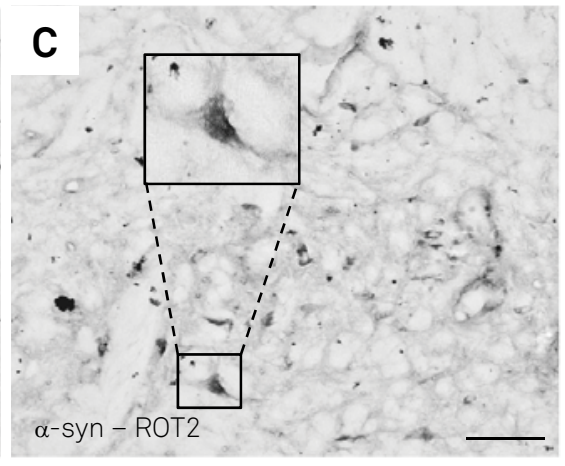

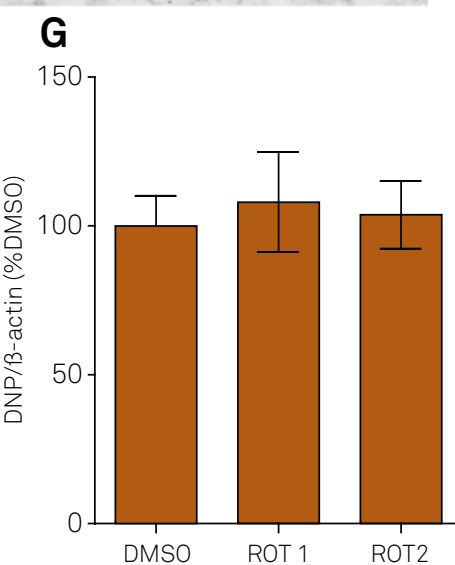

Figure 2. Illustrative digital images showing the pattern of alpha-synuclein ( $\alpha$-syn) immunoreactivity in the substantia nigra of 10 -month-old rats exposed to DMSO (A) or rotenone $(1 \mathrm{mg} / \mathrm{kg} /$ day, ROT1 (B) or $2 \mathrm{mg} / \mathrm{kg} / \mathrm{day}$, ROT2 (C)). Detail in C indicates a cell with dense cytoplasm labeling suggestive of aggregates containing $\alpha$-syn. Scale bar $=50 \mu m$. Representative images of immunoblot bands corresponding to hyperphosphorylated TAU ( $p$-TAU), alpha-synuclein and beta-actin and quantification of their expression ( $D$ and $E$ ) in the substantia nigra of aged rats exposed either to DMSO or rotenone. Protein carbonyls were evaluated using antibody against DNP (dinitrophenol) (F and G). Normalizations were performed by beta-actin signal. Values are shown as a percentage of the control (DMSO) $\pm S D$. * $p<0.05$ as compared to DMSO. The experiments were repeated twice, each was run in technical triplicate. 

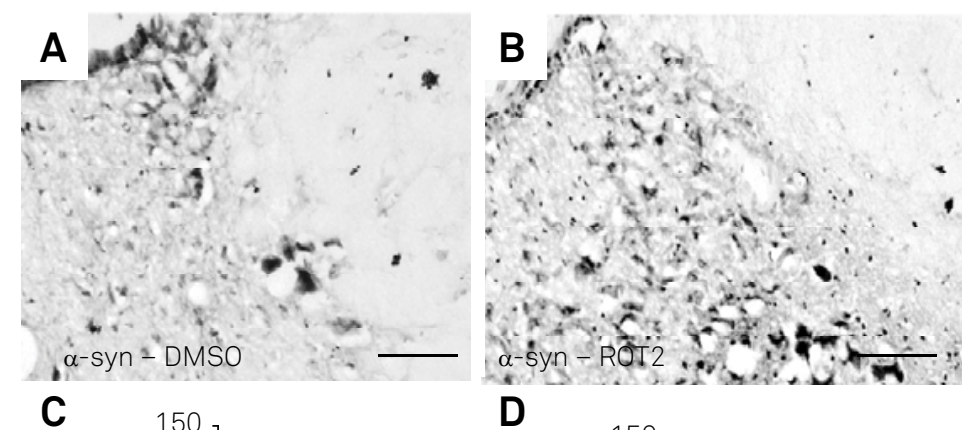

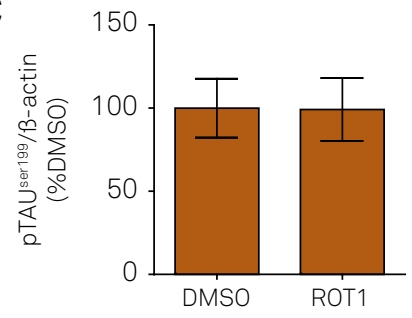

$\mathbf{E}$

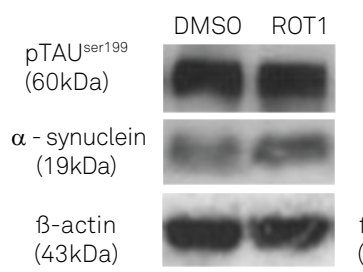

$\mathbf{F}$

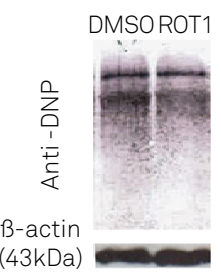

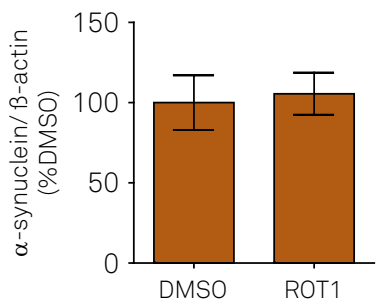

G

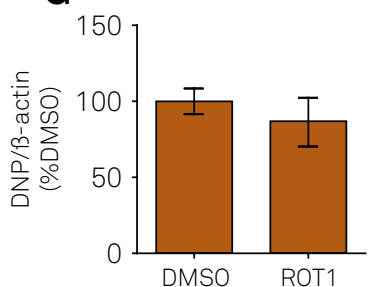

Figure 3. Illustrative digital images showing the pattern of alpha-synuclein ( $\alpha$-syn) immunoreactivity in the locus coeruleus of 10-month-old rats exposed to DMSO (A) or rotenone $2 \mathrm{mg} / \mathrm{kg} / \mathrm{day}$, ROT2 (B)). Scale bar $=50 \mu \mathrm{m}$. Quantification of

hyperphosphorylated TAU ( $p-T A U)(C)$ and alpha-synuclein (D) expression in the locus coeruleus of aged rats exposed either to DMSO or rotenone (1 mg/kg/day, ROT1). Representative images of immunoblot bands corresponding to p-TAU, alpha-synuclein and beta-actin (E). Protein carbonyls were evaluated using antibody against DNP (dinitrophenol) (F and G). Normalizations were performed by beta-actin signal. Values are shown as a percentage of the control (DMSO) $\pm S D$. Experiments were repeated twice, each was run in technical triplicate.

for this reason, it was not possible to perform any statistical analysis of labeling. Moreover, quantification of protein levels is more accurate through the western blot than immunohistochemistry, since it is possible to normalize data (using a housekeeping protein, such as beta-actin). The association between the western blot and imunohistochemistry techniques is necessary to evaluate the effects of rotenone upon protein expression and location, although the results from both techniques do not necessarily go in the same direction. For example, aggregation of protein can be detected by immunohistochemistry, while the amount of total protein may not be altered.

TAU is a multifunctional protein that stabilizes microtubules and is involved in intracellular trafficking of organelles and synaptic vesicles ${ }^{20}$. Rotenone's ability to trigger TAU hyperphosphorylation has been already demonstrated by Hoglinger and collaborators ${ }^{21}$, corroborating the data shown in this study for $2 \mathrm{mg} / \mathrm{kg} /$ day of rotenone in the hippocampus.

Alpha-synuclein is another protein involved in the neurodegenerative processes. It is a small and abundant pre-synaptic protein involved in synaptic transmission and plasticity, whose aggregation is present in Parkinson's disease. Previous studies using rotenone administration through minipumps at concentrations between $2.0-3.5 \mathrm{mg} / \mathrm{kg} /$ day in male Lewis rats demonstrated dysfunction in dopaminergic neurons, motor impairment, and cytoplasmic aggregates of alpha-synuclein ${ }^{22}$. The present results corroborate with these earlier studies showing alpha-synuclein aggregates in the substantia nigra after systemic exposure to $2 \mathrm{mg} / \mathrm{kg} /$ day of rotenone. In addition, the present study goes further and demonstrates alpha-synuclein aggregation in the locus coeruleus of aged Lewis rats submitted to rotenone exposure.

The delivery of rotenone subcutaneously, at concentrations over $3 \mathrm{mg} / \mathrm{kg} /$ day, promoted alpha-synucleinopathy associated with systemic toxicity, measured by the weight loss during the exposure to rotenone $e^{23,24}$. However, aged rats present increased specific sensitivity of dopaminergic neurons and lower systemic toxicity. In a previous study it was demonstrated that the administration of $1 \mathrm{mg} / \mathrm{kg} /$ day of rotenone, delivered systemically, affected neither body weight nor locomotor activity, suggesting a lack of peripheral toxicity and indicating that the observed changes were due to rotenone action on nerve cells ${ }^{25}$. In the present study the profile of hyperphosphorylated TAU, alpha-synuclein protein expression and beta amyloid formation in aged rats exposed to two different 
concentrations of rotenone demonstrates that these doses of rotenone are useful in approaching neurodegeneration in different ways.

Nonetheless, the most relevant results of the present study rely on rotenone at concentrations that do not trigger protein aggregation, opening new possibilities for the study of the earliest stages of neurodegeneration. This model is useful to study cell physiology in the absence of protein inclusions, which may indeed be important to cause proteins to aggregate.

Rotenone at 1 or $2 \mathrm{mg} / \mathrm{kg} /$ day did not increase the expression of monomeric forms of alpha-synuclein (correspondent bands of the $19 \mathrm{kDa}$ ) in any of the brain regions studied (hippocampus, substantia nigra and locus coeruleus). However, an aggregated form of alpha-synuclein was identified by immunocytochemistry analyses. A previous report has demonstrated that alpha-synuclein aggregation seems to depend on changes in the expression of their oligomeric forms, as the monomer forms do not appear to be altered in the presence of aggregates ${ }^{26}$.

As rotenone impairs mitochondrial function, it exacerbates the features present during the aging process and neurodegeneration. It is hypothesized that loss of mitochondrial efficacy is a common phenomenon for both aging and neurodegeneration processes ${ }^{27}$, mainly because of the increased oxidation levels of lipids, protein and nucleic acids that lead to impairment of cell function.

Dalle-Donne and collaborators ${ }^{28}$ demonstrated that the presence of carbonyl groups attached to proteins might indicate a more severe oxidative environment. In view of this, the present data corroborates that the low oxidative levels after exposure to rotenone in aged Lewis rats do not show changes in protein carbonyls.

In conclusion, it was demonstrated that a low dose of rotenone ( $1 \mathrm{mg} / \mathrm{kg} /$ day), did not cause an increase in TAU hyperphosphorylation, beta-amyloid formation, alpha-synuclein expression levels and oxidative stress in the brain of aged rats, validating the use of this model to study cellular mechanisms that may trigger protein aggregation. Moreover, the use of $2 \mathrm{mg} / \mathrm{kg} /$ day rotenone treatment allowed the study of the effects of protein aggregation in the central nervous system, as depicted in Figure 4.

\section{ACKNOWLEDGEMENTS}

The authors thank Dr. Rodrigo S. Chaves for his valuable critical reading of the manuscript.

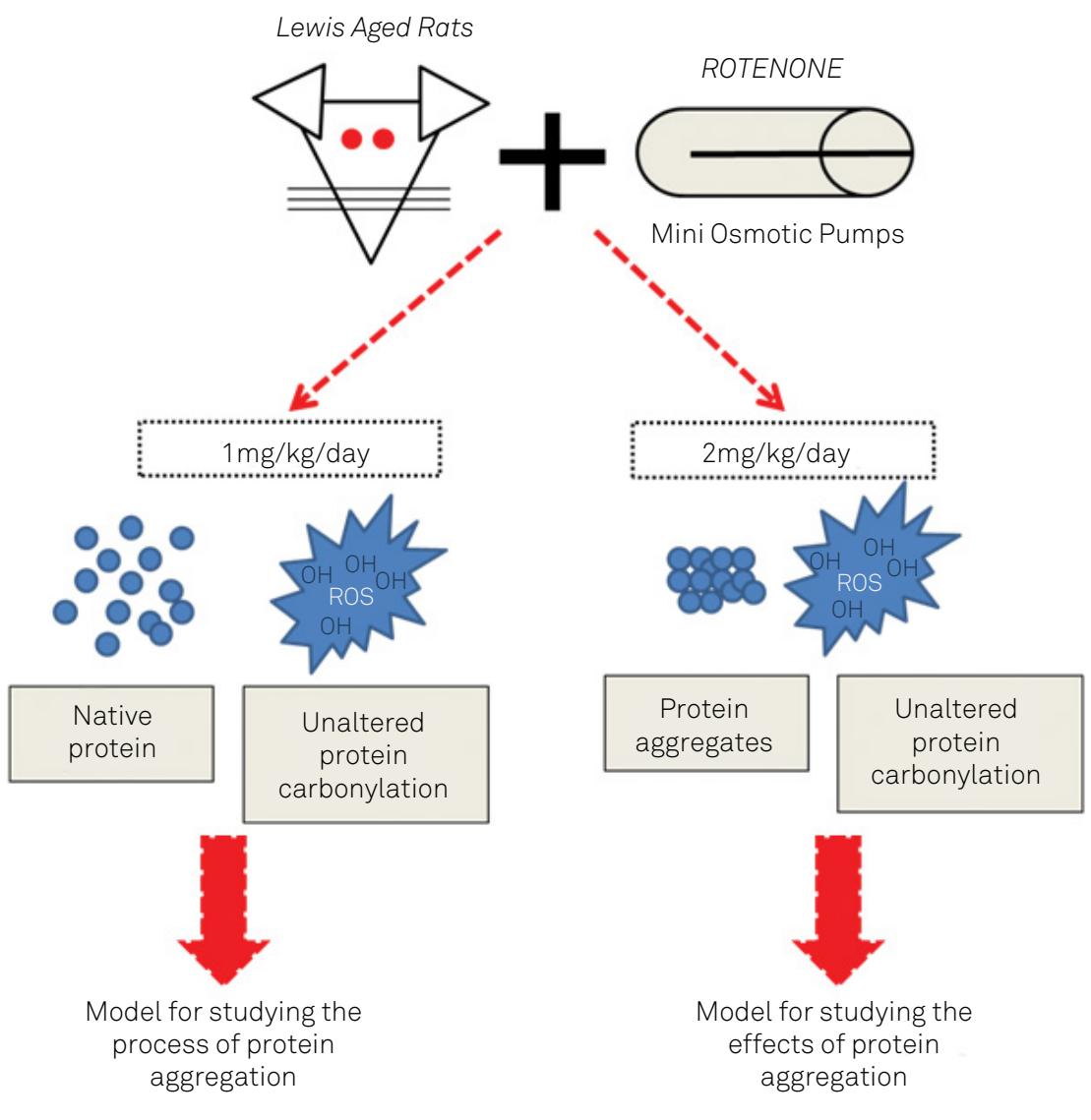

Figure 4. Overview of the results and conclusions achieved in this study. 
1. Kalache A, Gatti A. Active ageing: a policy framework. Adv Gerontol. 2003;11:7-18.

2. Ferrer I. Defining Alzheimer as a common age-related neurodegenerative process not inevitably leading to dementia. Prog Neurobiol. 2012;97(1):38-51. doi:10.1016/j.pneurobio.2012.03.005

3. Taipa R, Pinho J, Melo-Pires M. Clinico-pathological correlations of the most common neurodegenerative dementias. Front Neurol. 2012;3:68. doi:10.3389/fneur.2012.00068

4. Halliday GM, Holton JL, Revesz T, Dickson DW. Neuropathology underlying clinical variability in patients with synucleinopathies. Acta Neuropathol. 2011;122(2):187-204. doi:10.1007/s00401-011-0852-9

5. Hoover BR, Reed MN, Su J, Penrod RD, Kotilinek LA, Grant MK et al. Tau mislocalization to dendritic spines mediates synaptic dysfunction independently of neurodegeneration. Neuron. 2010;68(6):1067-81. doi:10.1016/j.neuron.2010.11.030

6. Riemer J, Kins S. Axonal transport and mitochondrial dysfunction in Alzheimer's disease. Neurodegener Dis. 2013;12(3):11-24. doi:10.1159/000342020

7. Xie W, Chung KK. Alpha-synuclein impairs normal dynamics of mitochondria in cell and animal models of Parkinson's disease. J Neurochem. 2012;122(2):404-14. doi:10.1111/j.1471-4159.2012.07769.x

8. Melo TQ, D'unhao AM, Martins SA, Farizatto KL, Chaves RS, Ferrari MF. Rotenone-dependent changes of anterograde motor protein expression and mitochondrial mobility in brain areas related to neurodegenerative diseases. Cell Mol Neurobiol. 2013;33(3):327-35. doi:10.1007/s10571-012-9898-z

9. Tang Y, Scott DA, Das U, Edland SD, Radomski K, Koo EH et al. Early and selective impairments in axonal transport kinetics of synaptic cargoes induced by soluble amyloid beta-protein oligomers. Traffic. 2012;13(5):681-93. doi:10.1111/j.1600-0854.2012.01340.x

10. Heras-Sandoval D, Ferrera P, Arias C. Amyloid- $\beta$ protein modulates insulin signaling in presynaptic terminals. Neurochem Res. 2012;37(9):1879-85. doi:10.1007/s11064-012-0800-7

11. Gaugler MN, Genc O, Bobela W, Mohanna S, Ardah MT, El-Agnaf $\mathrm{OM}$ et al. Nigrostriatal overabundance of alpha-synuclein leads to decreased vesicle density and deficits in dopamine release that correlate with reduced motor activity. Acta Neuropathol. 2012;123(5):653-69. doi:10.1007/s00401-012-0963-y

12. Fang C, Bourdette D, Banker G. Oxidative stress inhibits axonal transport: implications for neurodegenerative diseases. Mol Neurodegener. 2012;7(1):29. doi:10.1186/1750-1326-7-29

13. Umeda T, Tomiyama T, Sakama N, Tanaka S, Lambert MP, Klein WL et al. Intraneuronal amyloid $\beta$ oligomers cause cell death via endoplasmic reticulum stress, endosomal/lysosomal leakage, and mitochondrial dysfunction in vivo. J Neurosci Res. 2011;89(7):1031-42. doi:10.1002/jnr.22640

14. Stadtman ER, Berlett BS. Reactive oxygen-mediated protein oxidation in aging and disease. Drug Metab Rev 1998;30(2):225-43. doi:10.3109/03602539808996310
15. Xiong N, Long X, Xiong J, Jia M, Chen C, Huang J et al. Mitochondrial complex I inhibitor rotenone-induced toxicity and its potential mechanisms in Parkinson's disease models. Crit Rev Toxicol. 2012;42(7):613-32. doi:10.3109/10408444.2012.680431

16. Chaves RS, Melo TQ, Martins SA, Ferrari MF. Protein aggregation containing $\beta$-amyloid, $\alpha$-synuclein and hyperphosphorylated $\tau$ in cultured cells of hippocampus, substantia nigra and locus coeruleus after rotenone exposure. BMC Neurosci. 2010;11(1):144. doi:10.1186/1471-2202-11-144

17. Blesa J, Phani S, Jackson-Lewis V, Przedborski S. Classic and new animal models of Parkinson's disease.J Biomed Biotechnol. 2012;2012:845618. doi:10.1155/2012/845618

18. Isaacs AM, Senn DB, Yuan M, Shine JP, Yankner BA. Acceleration of amyloid beta-peptide aggregation by physiological concentrations of calcium. J Biol Chem. 2006;28 (38):27916-23. doi:10.1074/jbc.M602061200

19. Leuner K, Schutt T, Kurz C, Eckert SH, Schiller C, Occhipinti A et al. Mitochondrion-derived reactive oxygen species lead to enhanced amyloid beta formation. Antioxid Redox Signaling. 2012;16(12):1421-33. doi:10.1089/ars.2011.4173

20. Morris M, Maeda S, Vossel K, Mucke L. The many faces of tau. Neuron. 2011;70(3):410-26. doi:10.1016/j.neuron.2011.04.009

21. Höglinger GU, Lannuzel A, Khondiker ME, Michel PP, Duyckaerts $C$, Féger $\mathrm{J}$ et al. The mitochondrial complex I inhibitor rotenone triggers a cerebral tauopathy. J Neurochem. 2005;95(4):930-9. doi:10.1111/j.1471-4159.2005.03493.x

22. Fleming SM, Zhu C, Fernagut PO, Mehta A, DiCarlo CD, Seaman RL et al. () Behavioral and immunohistochemical effects of chronic intravenous and subcutaneous infusions of varying doses of rotenone. Exp Neurol. 2004;187(2):418-29. doi:10.1016/j.expneurol.2004.01.023

23. Sherer TB, Kim JH, Betarbet R, Greenamyre JT. Subcutaneous rotenone exposure causes highly selective dopaminergic degeneration and alpha-synuclein aggregation. Exp Neurol. 2003;179 (1):9-16. doi:10.1006/exnr.2002.8072

24. Alam M, Schmidt WJ. Mitochondrial complex I inhibition depletes plasma testosterone in the rotenone model of Parkinson's disease. Physiol Behav. 2004;83(3):395-400. doi:10.1016/j.physbeh.2004.08.010

25. Melo TQ, D'Unhao A M, Martins SA, Farizatto KL, Chaves RS, Ferrari MF. Rotenone-dependent changes of anterograde motor protein expression and mitochondrial mobility in brain areas related to neurodegenerative diseases. Cell Mol Neurobiol. 2013;33(3):327-35. doi:10.1007/s10571-012-9898-z

26. Winner B, Jappelli R, Maji SK, Desplats PA, Boyer L, Aigner S et al. In vivo demonstration that alpha-synuclein oligomers are toxic. Proc Natl Acad Sci USA. 2011;108(10):4194-9. doi:10.1073/pnas.1100976108

27. Leuner K, Hauptmann S, Abdel-Kader R, Scherping I, Keil U, Strosznajder JB. Mitochondrial dysfunction: the first domino in brain aging and Alzheimer"s disease? Antioxid Redox Signal. 2007;9(10):1659-75. doi:10.1089/ars.2007.1763

28. Dalle-Donne I, Giustarini D, Colombo R, Rossi R, Milzani A. Protein carbonylation in human diseases. Trends Mol Med. 2003;9(4):169-76. doi:10.1016/S1471-4914(03)00031-5 